УДК 342 (477)

DOI https://doi.org/10.32837/pyuv.v2i4(29).450

\author{
О. А. Моргунов \\ orcid.org/0000-0003-2259-3620 \\ кандидат юридичних наук, доцент, докторант \\ Харківського національного університету внутрішніх справ
}

\title{
ФУНКЦІї ПУБЛІЧНОГО АДМІНІСТРУВАННЯ СФЕР ФІЗИЧНОЇ КУЛЬТУРИ ТА СПОРТУ В УКРАЇНІ ЗА СУЧАСНИХ УМОВ
}

Постановка проблеми. Завдання статті - висвітлити функції як основні напрями діяльності суб'єктів публічного адміністрування сфер фізичної культури та спорту в Україні.

Аналіз останніх досліджень і публікацій. Питання функцій державного управління, як і публічного адміністрування, неодноразово ставали предметом досліджень, серед яких варто відзначити праці таких науковців, як О.Ф. Андрійко, І.Л. Бородін, К.Л. Бугайчук, І.Л. Гасюк, Л.Є. Кисіль, О.Д. Крупчан, В.Л. Коваленко та ін.

Невирішені раніше проблеми. Сьогодні мета публічного адміністрування перебуває у стані трансформації у зв'язку із впровадженням людиноцентриської теорії. У цьому сенсі змінюється і мета публічного адміністрування порівняно 3 метою державного управління, відповідно, змінюються його завдання та функції.

Метою статті $€$ визначення взаємного впливу та на цій основі -сучасного розуміння мети, завдань і функцій публічного адміністрування сфер фізичної культури та спорту в Україні в умовах відходу від парадигми управління людьми та владного розпорядництва до концепції обслуговування громадянського суспільства.

Виклад основного матеріалу. Як вказує І.Л. Бородін: «У публічному управлінні функції відображають його зміст. Зміст публічного управління це сукупність його процесів, відносин, зв'язків. Їх чисельність і різноманітність свідчить, наскільки складним є публічне управління. Функції мають самостійний, об'єктивний та універсальний характер і використовуються у різних сферах публічного управління. Вони є взаємопов'язаними і взаємозалежними та тісно інтегровані в процес публічного управління і становлять єдине ціле з ним. Уся їх сукупність розкриває управлінський процес. Таким чином, функції публічного управління - це самостійні та якісно однорідні складові частини діяльності суб'єктів публічного управління, об'єднані між собою єдиною метою, особливостями реалізації» [1, с. 24]. За визначенням К.Л. Бугайчук, функції публічного адміністрування слід визначити як зумовлені цілями та завданнями конкретні складники змісту публічного адміністрування, які мають об’єктивний, універсальний і державно-владний характер, склада- ються з груп відносно самостійних, однорідних дій, здійснюються уповноваженими суб'єктами [2, с. 115].

Можливою є систематизація функцій публічного адміністрування залежно від об'єкта управління, кінцевого результату тощо. Крім того, вони поділяються на внутрішні (управління всередині державної керуючої системи) і зовнішні (вплив державних органів на об'єкти управління), економічні, соціальні, соціально-виховні та ін. [1, с. 24-25]. Класифікація напрямів діяльності може враховувати складники суспільної реальності, в межах яких створюється каркас відповідних адміністративних відносин: 1) відносини між державою, суспільством і громадянами, на підставі і завдяки чому формуються управлінські впливи (управління суспільством із боку державного апарату), у цьому процесі першорядного значення набувають правові механізми об'єктивації й об'єктивізації державного управління; 2) відносини у межах держави, між ії інституціями 3 приводу розподілу предмету справ і державної влади, необхідної для здійснення управління. Провідним питанням цих відносин виступає визначення правового статусу державних органів; 3) вольові відносини між людьми, які залучені до державноуправлінських процесів, причому як із причин своєї професійної діяльності, так і звернення до державних органів задля вирішення власних проблем [3, с. 289-290]. Це означає, що функції суб'єктів публічного адміністрування можуть охоплювати зовнішне управління, внутрішньо-організаційні зв'язки.

Але традиційним і найбільш поширеним в адміністративному праві єїх поділ на:а) загальні; б)спеціальні; в) допоміжні (обслуговуючі) [1, с. 24-25]. Допоміжні функції адміністрування призначені для більш якісної реалізації основних функцій публічного адміністрування. За їх допомогою створюються необхідні умови для нормальної діяльності усіх управлінських структур [2, с. 116] це кадрова, матеріально-технічна, фінансова діяльність, діловодство та ін. Від них залежить ефективність управлінської діяльності. Вони забезпечують реалізацію двох перших функцій публічного управління і на практиці взаємодіють між собою та складають єдину систему впливу 
суб'єкта на об'єкт публічного управління [1, с. 24]. Такі функції ще позначаються як внутрішньо-орієнтовані. Вони уособлюють управління всередині керуючої системи. Їх існування озумовлене багаторівневою і різнокомпонентною побудовою системи суб'єктів публічного адміністрування. Для системи управління необхідно не тільки визначити мету управління та поставити завдання для іï досягнення, а ще й створити відповідні умови для ï виконання кожним елементом системи, встановити зв'язки між ними, забезпечити їх діяльність організаційно. Подібні завдання виконуються через внутрішньо-орієнтовані функції. Іншими словами, цільова орієнтація таких функцій полягає в тому, щоб надавати динамічності та законності керування кожному суб'єкту, удосконалювати і розвивати його, переводити у стан, що відповідає суспільним потребам у державному управлінні [4, с. 66-67]. Основною функцією програмно-технологічної структури І.Л. Гасюк пропонує визначати аналітичну діяльність відповідних комісій, спрямовану на адаптацію, визначення подальших пріоритетних шляхів розвитку фізичної культури і спорту за швидкоплинних умов навколишнього середовища, стандартизацію схем діяльності системи загалом у межах територіальної компетенції рад [5, с. 197-198].

Щодо загальних функції публічного адміністрування сфер фізичної культури та спорту, то вони $є$ універсальними та пристосованими до будь-яких управлінських процесів. Такі функції властиві всьому управлінському процесу для всіх рівнів управлінських структур. Вони відображають найбільш об’ємні завдання процесу публічного управління. До них належать: прогнозування, планування, регулювання, координація, облік і контроль [1, с. 25]. Прогнозування охоплює: передбачення можливих тенденцій соціально-економічного розвитку в контексті динаміки та напрямів, у т. ч. і загальносвітових трансформацій; передбачення варіантів і можливих наслідків прийнятих стратегічних і тактичних рішень у сфері соціально-економічного, науково-технічного, екологічного, зовнішньоекономічного розвитку; корегування, що сприяє своєчасному уточненню або скасуванню рішення, якщо цього вимагатимуть обставини [6, с. 28]. Важливим чинником сприяння ефективності діяльності органів державної влади України Н.П. Дяченко визначає за діяння механізмів впливу прогнозування на формування державно-управлінських рішень і стратегій розвитку [7, с. 99]. Для цього застосовується планування.

Планування - розробка змісту конкретних заходів із реалізації поставлених цілей і завдань, визначення конкретних виконавців і ресурсів, а також строків виконання [8, с. 36]. В основу стратегічного планування покладено розгорнутий стратегічний аналіз, де стратегія в широкому розумінні трактується як взаємопов’язаний комп- лекс заходів щодо підвищення життєдіяльності будь-якого об'єкта, а в практичному плані це генеральна довгострокова програма дій і порядок розподілу пріоритетів і ресурсів будь-якої структури для досягнення цілей. Основні завдання, які вирішуються під час розробки стратегічного плану розвитку будь-якого об'єкта, пов'язані з підвищенням його адаптованості до постійно змінюваних умов, а зрештою - із досягненням динамічної рівноваги в національній економіці загалом. Стратегічне планування - складовий елемент стратегічного управління, процес моделювання майбутньої діяльності на певний період [9, с. 38].

Регулювання як функція публічного адміністрування сфер фізичної культури та спорту проявляється у встановленні, скасуванні, коригуванні правил і меж поведінки учасників відповідних відносин [10, с. 4].

Функція координації забезпечує узгодженість дій всіх суб'єктів публічного адміністрування, допоміжної структури. Завдяки ній погоджуються дії не тільки окремих керівників і виконавців, але й окремих структурних підрозділів. Завдяки координації досягається злагодженість і єдність розробки та виконання управлінських рішень, забезпечується погодження спільних заходів, здійснюється інформаційний обмін [2, с. 116].

Облік як функція публічного адміністрування здійснюється задля забезпечення суб'єктів його здійснення корисною інформацією для планування, контролю та прийняття управлінських рішень. У системі управлінського обліку також здійснюється оцінка прийнятих рішень на різних рівнях управління та відповідності стратегії розвитку галузі. Досягнення мети базується на виконанні визначених завдань, які, з іншого боку, забезпечують функції управлінського обліку [11, с. 118]. Для сфер фізичної культури та спорту облік може бути використано для споживачів послуг відповідних сфер, якщо говорити про реєстри спортивних споруд, тренерів, спортсменів. Відкритість і доступність як принципи публічного адміністрування вказаних сфер таким чином будуть впроваджуватися.

Контроль є сукупністю дій зі спостереження за функціонуванням відповідного об'єкта контролю з метою: отримання об'єктивної та достовірної інформації про стан справ на ньому; застосування заходів попередження правопорушень (із правом прямого втручання в оперативну діяльність об'єкта контролю); надання допомоги підконтрольному об'єкту у поновленні законності та дисципліни; встановлення причин і умов, які сприяють порушенню вимог правових норм; вжиття заходів щодо притягнення винних осіб до юридичної відповідальності [12, с. 459]. Всі ці функції конкретизуються у спеціальних функціях, що для кожного рівня структури суб'єктів дещо відрізняються. 
Як пояснює І.Л. Бородін, спеціальні функції публічного управління дають можливість визначити особливості й умови публічного управління. Вони встановлюють специфіку того чи іншого суб'єкта або об’єкта публічного управління. Спеціальні (спеціалізовані) функції публічного управління за видами керованих об’єктів відображують особливості й умови управління, насамперед економікою, соціально-культурною і адміністративно-політична сферами [1, с. 24-25]. Провідними функціями суб'єктів публічного адміністрування в галузях фізичної культури і спорту «за будь-якої соціальноекономічної системи залишаються: визначення пріоритетів розвитку галузі, стратегічне планування та прогнозування, формування політики ресурсного, кадрового, інформаційного, медичного забезпечення діяльності галузі, створення сприятливих передумов для ведення господарської діяльності в галузі, організації фундаментальних і прикладних наукових досліджень і науково-методичного забезпечення фізкультурно-спортивної діяльності, формування необхідної законодавчої бази» [13, с. 129]. І всі ці та інші спеціальні функції публічного адміністрування розподілено між суб'єктами різного рівня ієрархії.

Для стратегічного апексу основною відмінною спеціальною функцією публічного адміністрування у сфері фізичної культури і спорту вважаємо формування та реалізацію політики у сферах фiзичної культури і спорту. О.І. Лавренова доходить висновку, що функція формування та реалізації державної політики у визначеній сфері є доволі специфічною. Така функція притаманна лише такому типу органів державного управління, як міністерства, і не може бути застосована до інших органів державного управління $[8$, с. 36], на відміну від інших функцій, аналіз яких сьогодні з погляду децентралізації влади актуальний і необхідний.

Як вказує І.Л. Гасюк, сьогодні характерним $\epsilon$ часткове делегування владних повноважень, адже контроль і визначення ефективності діяльності відповідних територіальних управлінських структур залишається за стратегічним апексом [5, с. 197]. Для середньої ланки спеціальні функції публічного управління у сферах фізичної культури та спорту охоплюють реалізацію політики у сферах фізичної культури і спорту, визначення пріоритетів розвитку у відповідних сферах, виконання програм і здійснення заходів, спрямованих на забезпечення розвитку фізичної культури та спорту, сприяння розвитку видів спорту, визнаних в Україні, громадським організаціям фізкультурно-спортивної спрямованості, розвитку олімпійського, паралімпійського та дефлімпійського руху, міжнародному співробітництву, здійсненню координації та контролю за дотриманням актів законодавства з питань молоді та спорту.
Місцеве самоврядування в Україні у сфері фізичної культури та спорту - це гарантоване державою право та реальна здатність територіальної громади самостійно або під відповідальність органів і посадових осіб місцевого самоврядування вирішувати питання місцевого значення у сфері фізичної культури та спорту в межах Конституції і законів України: управління закладами фізичної культури та спорту, організація медичного, фінансового, матеріального технічного тощо забезпечення закладів фізкультури і спорту, які належать територіальним громадам або передані їм, сприяння роботі громадських і неприбуткових організацій, що діють у сфері фізкультури і спорту, створення умов для занять фізичною культурою і спортом за місцем проживання населення та в місцях масового відпочинку громадян. До делегованих повноважень віднесено вирішення питань про надання неповнолітнім, учням, студентам, пенсіонерам та інвалідам права на безкоштовне і пільгове користування об'єктами фізкультури і спорту, а також визначення порядку компенсації цим закладам вартості послуг, наданих безкоштовно або на пільгових умовах [14, с. 142].

До основних функцій операційного ядра І.Л. Гасюк пропонує віднести: 1) створення бази виробництва послуг фізкультурно-оздоровчого характеру та задоволення потреб суспільства в реалізації права на заняття фізичною культурою та спортом; 2) створення необхідних і достатніх умов для виготовлення продукту галузі відповідної якості й у необхідній кількості, що регулюється через ринковий механізм попиту та пропозиціі; 3) врегулювання трансформаційних процесів виробництва фізкультурно-спортивних послуг відповідно до запитів суспільства» [5, с. 197]. Додамо, що до основних функцій публічного адміністрування сфер фізичної культури та спорту доцільно відносити функцію надання адміністративних послуг.

Є.І. Білокур стверджує про виділення надання адміністративних послуг як окремої функції публічного адміністрування [1, с. 168-169]. M.I. Ocлавський вказує, що інститут адміністративних послуг - це новий інститут адміністративного права, який з'явився внаслідок демократизації української держави та визнання за нею нової публічно-сервісної, обслуговуючої функції [15, с. 45]. О.І. Лавренова доходить висновку, що ця функція має пріоритетне значення [8, с. 36-37]. Така переорієнтація є наслідком переходу від традицій «владного розпорядництва" до «надання послуг» (або «обслуговування») громадянам та інших приватних осіб [16, с. 510].

O.I. Лавренова стверджує, що більшість функцій суб'єктів публічного адміністрування мають складати функції з надання адміністративних послуг фізичним і юридичним особам [8, с. 36-37]. Однак така позиція потребує уточнення в тому, 
що здійснювати публічні послуги може як публічна адміністрація, так і альтернативні структури, створені з ініціативи органів влади у співпраці 3 громадськими організаціями. Фінансування надання послуг здійснюється переважно за рахунок коштів державного чи місцевого бюджетів і контролюється органами, які наділені державно-владними повноваженнями [17, с. 257-258]. I таке уточнення має визначальне значення для сфер фізичної культури та спорту, де громадські організації сьогодні складають окрему розгалужену функціонально-допоміжну структуру щодо системи суб'єктів публічного адміністрування.

Адміністративна послуга - це результат здійснення владних повноважень суб'єктом надання адміністративних послуг за заявою фізичної або юридичної особи, спрямований на набуття, зміну чи припинення прав та/або обов'язків такої особи відповідно до закону [8, с. 36-37]. Дефініція «послуги» акцентує увагу на виконанні саме обов'язків держави перед приватними особами, спрямованих на юридичне оформлення умов, необхідних для забезпечення належної реалізації ними своїх прав і охоронюваних законом інтересів. Таке розуміння повніше відповідає новій ідеології «служіння держави» інтересам людини [16, с. 510] і передбачає розуміння під публічними послугами всіх сервісних дій, що надаються публічним сектором або іншими суб'єктами під відповідальність публічної влади і за рахунок публічних коштів. Публічними послугами може бути визначена не лише публічно-владна діяльність, але і їі peзультати, спрямовані на реалізацію прав, свобод і законних інтересів фізичних і юридичних осіб [17, с. 257-258].

Висновки. Сучасні завдання та функції публічного адміністрування у сфері фізичної культури і спорту зумовлені його метою як орієнтиром розвитку відповідної системи як бажаного спрямування її діяльності. Відхід від парадигми управління людьми та владного розпорядництва до концепції обслуговування громадянського суспільства владою тягне перегляд всіх категорій адміністративного права, що стосуються цілепокладання. У контексті розвитку теорії публічного адміністрування такі зміни включають доцільність визначення метою публічного адміністрування сфер фізичної культури та спорту забезпечення прав, свобод та інтересів людини і громадянина на основі побудови партнерських відносин між владою і суспільством, що, у свою чергу, дозволяє метою функціонування публічної адміністрації у вказаних серах визначити служіння суспільству.

Реалізація мети досягається шляхом розробки системи цілей (які можуть бути закріплені у програмно-цільових актах з розробкою планів реалізації), регламентації завдань і функцій суб'єктів публічного адміністрування сфер фізичної куль- тури та спорту. Цілі можуть змінюватися, коли певні з них досягнуто. Мета, завдання та функції $€$ порівняно з цілями більш сталими положеннями щодо загального спрямування та конкретизованих напрямів діяльності конкретних суб'єктів організаційної структури публічного адміністрування сфер фізичної культури та спорту.

Напрями діяльності суб'єктів публічного адміністрування сфер фізичної культури та спорту, зумовлені завданнями, включають загальні функції, притаманні всім суб'єктам публічного адміністрування, незалежно від сфери та рівня в ієрарxiї, спеціалізовані, відмінні для кожного рівня організаційної структури функції, та допоміжна, які слугують забезпеченню виконання загальних і спеціальних. Реформа децентралізації влади передбачає перерозподіл спеціальних функцій між ланками системи різних рівнів, для чого з вищих рівнів ряд функцій доцільно передати на нижчі ланки та на виконання функціонально-допоміжної структури.

\section{Jimepamypa}

1. Бородін І.Л. Функції публічного управління. Юридичний вісник. Повітряне і космічне право. 2014. № 3. C. 24-29.

2. Бугайчук К.Л. Функції публічного адміністрування в органах Національної поліції: поняття та класифікація. Підприємництво, господарство і право. 2018. № 5 (267). С. 112-117.

3. Атаманчук Г.В. Теория государственного управления : курс лекций. Москва : Омега-Л, 2006. $584 \mathrm{c}$.

4. Білокур Є.І. Функції державного управління в межах керуючої системи. Право та державне управління. 2016. № 4. С. 66-71.

5. Гасюк І.Л. Організаційна структура державного управління фізичною культурою та спортом в Україні. Університетські наукові записки. 2010. № 3. C. 195-203.

6. Дяченко Н.П. Прогнозування в органах державної влади: організаційно-правовий аспект : дис. ... канд. наук з держ. упр. : 25.00.02 / НАДУ при Президентові України. Київ, 2018. 245 с.

7. Дяченко Н.П. Прогнозування як складова аналітичної діяльності органів державної влади. Ефективність державного управління. 2016. Вип. 4. C. $92-100$.

8. Лавренова O.I. Загальна характеристика функцій державної служби як центрального органу виконавчої влади. Наше право. 2014. № 6. С. 34-39.

9. Лікарчук Н.В. Сутність стратегії планування як функції управління. Вісник Київського національного університету ілені Тараса Шевченка. Державне управління. 2014. Вип. 1. С. 37-40.

10. Білокур Є.I. Функції державного управління: поняття, особливості, правове регулювання : автореф. дис. ... канд. юрид. наук. Одеса, 2015. 23 с.

11. Фоміна О.В. Розвиток функцій управлінського обліку. Науковий вісник Ужгородського національного університету. Серія : Міжнародні економічні відносини та світове господарство. 2016. Вип. 6 (3). C. 117-120.

12. Виконавча влада і адміністративне право / О.Ф. Андрійко, Н.В. Кпіма, Л.Є. Кисіль, О.Д. Крупчан, 
В.Л. Коваленко та ін. ; за заг. ред. В.Б. Авер'янова. Київ : Видавничий Дім «Ін-Юре», 2002. 668 с.

13. Гасюк І.Л. Пріоритетні напрями удосконалення системи державного управління фізичною культурою і спортом. Еконоліка та держава. 2013. № 11. C. $129-132$.

14. Шевчук I.В. Нормативно-функціональні та методологічні засади формування державного управління фізичною культурою і спортом на рівні адміністративно-територіального утворення. Iнвестииії: практика та досвід. 2015. № 1. С. 141-145.

15. Ославський M.I. Аналіз новел закону «Про адміністративні послуги». Актуальні проблеми вдосконалення чинного законодавства України. 2012. Вип. 30. С. 45-52.

16. Берлач Н.А. Трансформація відносин між виконавчою владою та суспільством у процесі здійснення адміністративної реформи в Україні. Університетські наукові записки. 2012. № 1. С. 509-515.

17. Курс адміністративного права України : підручник / В.К. Колпаков, О.В. Кузьменко, І.Д. Пастух, В.Д. Сущенко та ін. / за ред. В.В. Коваленка. Київ : Юрінком Інтер, 2012. 808 с.

\section{Анотація}

Моргунов О. А. Функції публічного адміністрування сфер фізичної культури та спорту в Україні за сучасних умов. - Стаття.

У статті визначено взаємний вплив і сучасне розуміння мети, завдань і функцій публічного адміністрування сфер фізичної культури та спорту в Україні в умовах відходу від парадигми управління людьми та владного розпорядництва до концепції обслуговування громадянського суспільства. Визначено, що сучасні завдання та функції публічного адміністрування у сфеpi фізичної культури і спорту зумовлені його метою як орієнтиром розвитку відповідної системи як бажа-

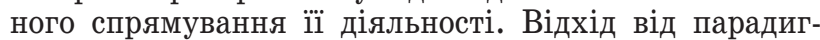
ми управління людьми та владного розпорядництва до концепції обслуговування громадянського суспільства владою тягне перегляд всіх категорій адміністративного права, що стосуються ціле покладання. У контексті розвитку теорії публічного адміністрування такі зміни включають доцільність визначення метою публічного адміністрування сфер фізичної культури та спорту - забезпечення прав, свобод та інтересів людини і громадянина на основі побудови партнерських відносин між владою і суспільством, що, у свою чергу, дозволяє метою функціонування публічної адміністрації у вказаних серах визначити служіння суспільству. 3'ясовано, що реалізація мети досягається шляхом розробки системи цілей (які можуть бути закріплені у програмно-цільових актах із розробкою планів реалізації), регламентації завдань і функцій суб'єктів публічного адміністрування сфер фізичної культури та спорту. Мета, завдання та функції є порівняно з цілями більш сталими положеннями щодо загального спрямування та конкретизованих напрямків діяльності конкретних суб'єктів організаційної структури публічного адміністрування сфер фізичної культури та спорту. Зроблено висновок, що напрями діяльності суб'єктів публічного адміністрування сфер фізичної культури та спорту, зумовлені завданнями, включають загальні функції, притаманні всім суб'єктам публічного адміністрування, незалежно від сфери та рівня в ієрархії, спеціалізовані, відмінні для кожного рівня організаційної структури функції, та допоміжна, які слугують забезпеченню виконання загальних і спеціальних. Реформа децентралізації влади передбачає перерозподіл спеціальних функцій між ланками системи різних рівнів, для чого з вищих рівнів ряд функцій доцільно передати на нижчі ланки та на виконання функціонально-допоміжної структури.

Ключові слова: мета публічного адміністрування, завдання публічного адміністрування, публічне адміністрування сфер фізичної культури та спорту, належне врядування.

\section{Summary}

Morhunov 0 . A. Functions of public administration in physical culture and sports in Ukraine in the current context. - Article.

The article defines the mutual influence and, on this basis, a modern understanding of the goals, objectives and functions of public administration of the areas of physical education and sports in Ukraine in the context of moving away from the paradigm of managing people to the concept of serving civil society. It is determined that the modern tasks and functions of public administration in the field of physical culture and sports are determined by its purpose as a guide for the development of the respective system as a desirable direction of its activity. Moving away from the paradigm of people management and authority to the concept of civil society servicing by the authorities, there is a reconsideration of all categories of administrative law that relate to the whole. In the context of the development of the theory of public administration, such changes include the expediency of defining the purpose of public administration of the spheres of physical culture and sport - ensuring the rights, freedoms and interests of the individual and the citizen on the basis of building partnerships between the authorities and society, which in turn allows the purpose of the functioning of public administration in the specified serums to determine service to the community. It is established that the achievement of the goal is achieved through the development of a system of goals (which can be enshrined in the program-target acts with the development of implementation plans), regulation of tasks and functions of subjects of public administration of the physical culture and sports. The purpose, tasks and functions are in comparison with the goals more stable provisions on the general direction and specific directions of activity of specific subjects of the organizational structure of the public administration of the spheres of physical culture and sports. It is concluded that the directions of activity of the subjects of public administration of the spheres of physical culture and sports, conditioned by the tasks, include the general functions inherent in all subjects of public administration, regardless of the sphere and level in the hierarchy, specialized, different for each level of organizational structure of the function, and ancillary services that serve the general and special. The reform of decentralization of power implies the redistribution of special functions between the links of the system of different levels, for which it is expedient to transfer a number of functions to the lower levels and to perform a functional support structure from higher levels.

Key words: goal of public administration, tasks of public administration, public administration of the areas of physical education and sports, good governance, good administration. 